\title{
XVIII. An account of some geological specimens, collected by Captain P. P. King, in his survey of the coasts of Australia, and by Robert Brown, Esq., on the shores of the gulf of Carpentaria, during the voyage of Captain Flinders
}

\author{
William Henry Fitton M.D. F.R.S. V.P.G.S.
}

To cite this article: William Henry Fitton M.D. F.R.S. V.P.G.S. (1826) XVIII. An account of some geological specimens, collected by Captain P. P. King, in his survey of the coasts of Australia, and by Robert Brown, Esq., on the shores of the gulf of Carpentaria, during the voyage of Captain Flinders, Philosophical Magazine Series 1, 68:340, 132-147, DOI: $10.1080 / 14786442608674098$

To link to this article: http://dx.doi.org/10.1080/14786442608674098

Published online: 10 Aug 2009.

Submit your article to this journal $₫$

山 Article views: 2

View related articles $\llbracket$ 
pilatam ramis strictioribus vidi in ditissimo regio horto absque floribus. Fortè vera species. Simulat M. brevifolium parùm, at non effuse ramosum ut in illo, neque confertum.

XVIII. An Account of some Geological Specimens, collected by Captain P. P. KING, in his Survey of the Coasts of Australia, and by RoBert Brown, Esq., on the Shores of the Gulf of Carpentaria, during the Voyage of Captain FuIN DERs. By William Henry FitTon, M.D. F.R.S. V.P.G.S.

[Continued from p. 34.]

VI. A $S$ the superficial extent of Australia is more than A three-fourths of that of Europe, and the interior may be regarded as unknown*, any theoretic inferences, from the slight geological information hitherto obtained respecting this great island, are very likely to be deceitful; but among the few facts already ascertained respecting the northern portion of it, there are some which appear to afford a glimpse of general structure.

Captain Flinders, in describing the position of the chains of islands on the north-west coast of Carpentaria, Wessell's, the EnglishCompany's, and Bromby's Islands, remarks, that he had " frequently observed a great similarity both in the ground plans, and the elevations of hills, and of islands, in the vicinity of each other, but did not recollect another instance of such a likeness in the arrangement of clusters of islands.+ " The appearances which called for this observation, from a voyager of so much sagacity and experience in physical geography, must probably have been very remarkable; and, combined with information derivable from the charts, and from the specimens for which we are indebted to Captain King and Mr.

* The following are the proportions assigned by Captain de Freycinet to the principal divisions of the globe.-Vayage aux Terres Australes, p. 107.

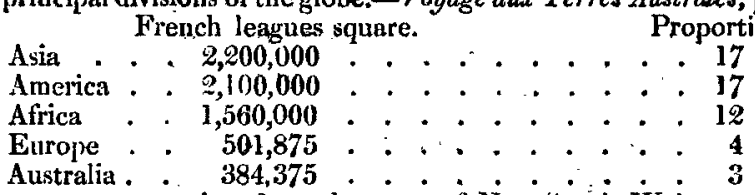

The most remote points from the coast of New South Wales, to which the late expeditions have penetrated, (and the interior hos never yet been examined in any other quarter, are not above 500 miles, in a direct line, from the sea; the average width of the island from east to west being more than 2000 miles, and from north to south more than 1000 miles.

+ Flinders, v. ii. p. 246 ; and Charts, Plates 14 and 15.-King's Charts, Plate 4. 
Brown, they would seem to point out the arrangement of the strata on the northern coasts of $\mathrm{New}$ Holland.

Of the three ranges which attracted Capt. Flinders's notice, (see the map, fig. 4 , in Pl. I.*) the first on the south-east, $(3,4,5$, 6,7, ) is that which includes the Red Cliffs, Mallison's Island, a part of the coast of Arnhem's Land, from Cape Newbold to Cape Wilberforce, and Bromby's Isles; and its length, from the main land (3) on the south-west of Mallison's Island, to Bromby's Isles (7) is more than fifty miles, in a direction nearly from south-west to north-east. 'The English Company's Islands, $(2,2,2,2$,$) at a distance of about four miles, are of equal ex-$ tent; and the general trending of them all, Captain Flinders states (p. 23.3), is nearly N.E. by E., " parallel with the line of the main coast, and with Bromby's Islands."-Wessell's Islands, $(1,1,1,1$,$) the third or most northern chain, at four-$ teen miles from the second range, stretch out to more than eighty miles from the main land, likewise in the same direction.

It is also stated by Captain Flinders, that three of the English Company's Islands which were examined, slope down nearly to the water on their west sides; but on the east, and more especially the south-east, they present steep cliffs; and the same conformation, he adds, seemed to prevail in the other islands + . If this structure occurred only in one or two instances, it might be considered as accidental; but as it obtains in so many cases, and is in harmony with the direction of the ranges, it is not improbably of still more extensive occurrence, and would intimate a general elevation of the strata towards the south-east.

Now on examining the general map, it will be seen, that the lines of the coast on the main land, west of the Gulf of Carpentaria, between Limmen's Bight and Cape Arnhem,from the bottom of Castlereagh Bay to Point Dale,-less distinctly from Point Pearce, lat. $14^{\circ} 23^{\prime}$, long. $129^{\circ} 18^{\prime}$, to the western extremity of Cobourg Peninsula, -and from Point Coulomb, lat. $17^{\circ} 20^{\prime}$, long. $123^{\circ} 11^{t}$, to Cape Londonderry, have nearly the same direction; - the first line being about one hundred and eighty geographical miles, the second more than

* The following is an explanation of this map:
A Castlereagh Ba
1,1 \&c.-Wessell's Islands.
B Point Dale
C Arnhem Bay
D Melville Bay
E Cape Arnhem
F Caledon Bay
2, \& \& c. - The English Company's Islands
(3- Red Cliffs
4 - Mallișon's Island
$\left\{\begin{array}{l}\mathbf{5}-\text { Cape Newbold } \\ \text { - Capilo }\end{array}\right.$
6 Cape Wilherforce
( 7 Bromby's Islands.

† Flinders, vol. ii. p. 233 . 
three hundred, and the last more than four hundred miles, in length*. And these lines, though broken by numerous irregularities, especially on the nortb-west coast, are yet sufficiently distinct to indicate a probable connexion with the geological structure of the country; since the coincidence of similar ranges of const with the direction of the strata, is a fact of very frequent ccurrence in other parts of the globet. And it is observalale that considerable uniformity exists in the specimens, from the different places in this quarter of New Holland which have been hitherto examined; sandstone like that of the older formations of Europe occurring generally on the north and north-west coasts, and appearing to be extensively diffused on the north-west of the Gulf of Carpentaria, where it reposes upan primitive rocks .

The horn-like projection of the land, on the east of the Gulf of Carpentaria, is a very prominent feature in the general map of Australia, and may possibly have some connexion with the structure just pointed out. The western shore of this horn, from the bottom of the gulf to Endeavour Straits, being very low; while the land on the east coast rises in proceeding towands tha south, and after passing Cape Weymouth, latitude

- It is deserving of notice, that the coast of Timor, the nearest land on the north-west, at the distance of about 300 miles, is also nearly straight, and parallel to the Coast of New Holland in this quarter : part of the mountainous range, of which that island cansists, being probably more than 9000 feet high; and its length, from the north-eastern extreuity to the S.W. of the adjoining island of Rottee, about 300 miles.- But, unforcontely for the hypotiresis; a chain of islands immediately on the north of Timor, is continued nearly in a right line for more than 1200 miles, (from Sermatta Island to the south.eastern extremity of Java, ) in a direction from ecist to west. This chain, however, contains several volcanoes, inclading these of Sumbawa, the eruption of which, in 1815 , was of extraor. dirrary volence. See R. Inst. Journal, vol. i. (1816), p. 248, \&c.

At Lacrosse Island, in the nouth of Cambridge Gulf, on the north-west corst of New Holland, the beds rise to the N.W.: their direction consepuently is from S.W. to N.E.; and the rise towards the high land of Timor. The fintervening ses is very shallow.

f A remarkable case of this kind, which has not, I believe, been noticed, occurs in the Mediterranean; and is conspicnous in the new chart of that sea, by Captain W. H. Smyth. The eastern coast of Corsica and Sardinia, for a space of more than two hundred geographical miles being nearly rectilinear, in a direction from north to south; and, Captain Smyth has informed me, consisting almost entirely of granite, or, at least, of primitive rocks. The coast of Norway affords another instance of the same descriptien; and the details of the ranges in the interior of England furnish several examples of the same kind, on a smaller scale.

\# The coast lines nearly at right angles to those above mentioned-from the S.E. of the Gulf of Carpentaria to Limmen's Bight,-from Cape Arnhem to Cape Croker, - and from Cape Domett to Cape Londonderry,have also a certain degree of linearity; but much less remarkable, than those which run from S.W. to N.E. 
$12^{\circ} 30^{\prime}$, is in general mounrainous and abrupt ; and Captain King's specimens from the north-east coast, show that granite is found in so many places along this line, as to make it probable that primitive rocks may form the general basis of the country in that quarter; since a lofty chain of mountains is continued on the south of Cape Tribulation, not far from the shore, throughout a space of more than five hundred miles: It would carry this hypothesis too far, to infer that these primitive ranges are counected with the mountains on the west of the English settlements near Port Jackson, \&c., where Mr. Scott has described the coal-measures as occapying the coast from Port Stevens, about lat. $33^{\circ}$ to Cape Howe, lat. $37^{\circ}$, and as succeeded, on the eastern ascent of the Blue Mountains, by sand-stone, and this again by primitive strata*:-But it may be noticed, that Wilson's Promontory, the most southern point of New South Wales, and the principal islands in Bass's Straits, contain granite; and that primitive rocks occur extensively in Van Diemen's Land.

The uniformity of the coast lines is remarkable also in some other quarters of Australia ; and their direction, as well as that of the principal openings, has a general tendency to a course from the west of south to the east of north. This, for example, is the general range of the south-east coast, from Cape Howe, about lat. $37^{\circ}$, to Cape Byron, lat. $29^{\circ}$, or even to Sandy Cape, lat. $25^{\circ}$; and of the western coast, fiom the south of the islands which enclose Shark's Bay, lat. $26^{\circ}$, to Northwest Cape, about lat. $22^{\circ}$. - From Cape Hamelin, lat. 34. 12', to Cape Naturaliste, lat. $33^{\circ} 26^{\prime}$, the coast runs nearly on the meridian. The two great fissures of the south coast, Spencer's, and St.Vincent's Gulfs, as well as the great northern chasm of the Gulf of Carpentaria, have a corresponding direction ; and Captain Flinders (Chart 4.) represents a high ridge of rocky and barren mountains, on the east of Spencer's Gulf, as continued, nearly from north to south, through a space of more than one hundred geographical miles, between latitude $32^{\circ} 7^{\prime}$ and $34^{\circ}$.-Mount Brown, one of the summits of this ridge, about latitude $32^{\circ} 30^{\prime}$, being visible at the distance of twenty leagues.

The tendency of all this evidence is somewhat in fayour of a general parallelism in the range of the strata, -and perhaps of the existence of primary ranges of mountains on the east of Australia in general, from the coast about Cape Weymouth $\uparrow$

* Annals of Philosophy, June 1824.

$\dagger$ The possible correspondence of the grcat Australian Bight, the coast of which in general is of no great elevation, with the deeply-indented Gulf of Carpentaria,-tending, as it were, to a division of this great island into 
to the shore between Spencer's Gulf and Cape Howe. But it must not be forgotten, that the distance between these shores is more than a thousand miles in a direct line; - about as far as from the west coast of Ireland to the Adriatic, or double the distance between the Baltic and the Mediterranean.-If, however, future researches should confirm the indications above mentioned, a new case will be supplied in support of the principle long since advanced by Mr. Michell*, which appears (whatever theory be formed to explain it,) to be established by geological observation in so many other parts of the world,that the outcrop of the inclined beds, thronghout the stratified portion of the globe, is every where parallel to the longer ridges of mountains, - towards which, also, the elevation of the strata is directed. But in the present state of our information respecting Australia, all such general views are so very little more than mere conjecture, that the desire to furnish ground for new inquiry, is, perhaps, the best excuse that can be offered for having proposed them.

\section{Detailed List of Specimens.}

The specimens mentioned in the following list have been compared with some of those of England and other countries, principally in the cabinets of the Geological Society, and of Mr. Greenough; and with a collection from part of the confines of the primitive tracts of England and North Wales; formed by Mr. Arthur Aikin, and now in his own possession. Captain King's collection has been presented to the Geological Society; and duplicates of Mr. Brown's specimens are deposited in the British Museum.

Rodn's Bay, on the East Coast, discovered by Capt. King; about sixty miles south of Cape Capricornt.-Reddish sandstone, of moderately-fine grain, resembling that which in England occurs in the coal formation, and beneath it (mill-stone grit). A sienitic compound, consisting of a large proportion

two, accords.with this hypothesis of mountain ranges: but the distance between these recesses, over the land at the nearest points, is not less than a thousand English miles. - The granite, on the south coast, at Investigator's Islands, - and westward, at Middle Island, Cape Le Grand, King George's Sound, and Cape Naturaliste, is very wide of the line above mentioned, and nothing is yet known of its relations.

* On the Cause of Earthquakes.-Philosophical Transactions; 1760, vol. li. p. $566-585,586$.

+ In Captain King's collection are also specimens found on the beach at Port Macquarie, and in the bed of the Hastings River, of common ser. pentine, and of botryoidal magnesite, from veins in serpentine. The magnesite agrees nearly with that of Baudissero, in Piedmont. (See Cleaveland's Mineralogy, Ist edition, p. 345.) 
of reddish felspar, with specks of a green substance, probably mica;-resembling a rock from Shap in Cumberland.

Cape Clnnton, between Rodd's Bay and the Percy Islands. -Porphyritic conglomerate, with a base of decomposed felspar, inclosing grains of quartz and common felspar, and some fragments of what appears to be compact epidote; very nearly resembling specimens from the trap rocks* of the Wrekin and Breeden Hills in Shropshire. Reddish and yellowish sandy clay, coloured by oxide of iron, and used as pigments by the natives.

Percy Islands, about one hundred and forty miles north of Cape Capricorn.-Compact felspar of a flesh-red hue, inclosing a few small crystals of reddish felspar and of quartz: This specimen is marked "general character of the rocks at Percy Island," and very much resembles the compact felspar of the Pentland Hills near Edinburgh, and of Saxony. Coarse porphyritic conglomerate, of a reddish hue. Serpentine. A traplike compound, with somewhat the aspect of serpentine; but yielding with difficulty to the knife-This specimen has, at first sight, the appearance of a conglomerate, made up of portions of different hues, purplish, brown, and green ; but the coloured parts are not otherwise distinguishable in the fractare: -It very strongly resembles a rock which occurs in the trapformation, near Lyd-Hole, at Pont-y-Pool, in Shropshire. Slaty clay, with particles of mica, like that which frequently occurs immediately beneath beds of coal.

Repulse Island, in Repulse Bay, about one hundred and twenty miles north-west of the Percy Islands.-Indistinct specimens, apparently consisting of decomposed compact felspar. A compound of quartz, mica, and felspar, having the appearance of re-composed granite.

Cape Claverand, about one hundred and twenty miles north of Repulse Island.-Yellowish-gray granite, with brown miex; "from the summit of the hill." ...Reddish granite, of very fine grain; with the aspect of sand-stone. Dark gray

* By the terms Trap, and Trap-formation, which I am aware are extremely vague, I intend merely to signify a class of rocks, including seyeral members, which differ from each other considerably in mineralogical character, but agree in some of their princigal geological relations $f$ and the origin of which very numerous phrenothena concur'in referring to same modification of volcanic agency: The term Greemedome also js of very loose application, and includes rocks that exhibit a wide range of characters; the predominant colour being some shade of greep, the structure more or less crystalline, and the chief ingredients supposed to be hornblende and felspar,-but the components, if they could be accurately determined; probably more numerous and varied, than systematic lists imply.

Vol. 68. No. 34.0. Aug. 1826. 
porphyritic hornstone, approaching to compact felspar, with imbedded crystals of felspar.

Cape Grafton, about one hundred and eighty miles west of north from Cape Cleveland.-Close-grained gray and yellowish-gray granite, with brown mica. A reddish granitic stone, composed of quartz, felspar, and tourmaline.

Endeavour River, about one hundred miles west of north from Cape Grafton.-Gray granite of several varieties; from a peaked hill under Mount Cook and its vicinity. Granular quartz-rock of several varieties: and indistinct specimens of a rock approaching to talc-slate.

LIzard Island, about fifty miles east of north from EndeavourRiver-Gray granite, consisting of brown and white mica, quartz, and a large proportion of felspar somewhat decomposed.

Clack Island, near Cape Flinders, on the north-west of Cape Melville, about ninety miles north-west of Lizard Island. -Smoke-gray micaceous slaty-clay, much like certain beds of the old red sand-stone, where it graduates into grey wacke. This specimen was taken from an horizontal bed about ten feet in thickness, reposing upon a mass of pudding-stone, which included large pebbles of quartz and jasper; and above it was a mass of sand-stone, more than sixty feet thick.-(Narrative, vol. ii. p. 26.)

Sunday Island, near Cape Grenville, about one hundred and seventy miles west of north from Cape Melville.-Compact,felspar, of a flesh-red colour; very nearly resembling that of the Percy Islands, above mentioned.

Good's Island, one of the Prince of Wales's group, about latitude $10^{\circ}$, thirty-four miles north-west of Cape York.-The specimens, in Mr. Brown's collection from this place, consist of coarse-slaty porphyritic conglomerate, with a base of greenishgray compact felspar, containing crystals of reddish felspar and quartz. This rock has some resemblance to that of Clack Island above mentioned.

SwEER's ISLAND, south of Wellesley's group, at the bottom of the Gulf of Carpentaria.-A stalactitic concretion of quartzose sand, and fine gravel, cemented by reddish carbonate of lime; apparently of the same nature with the stem-like concretions of King George's Sound: (See p. 146). In this specimen the tubular cavity of the stalactite is still open.

The shore, in various parts of this island, was found to consist of red ferruginous matter, (Bog-iron-ore?) sometimes unmixed, but not unfrequently mingled with a sandy calcareous stone; and in some places rounded portions of the ferruginous matter were enveloped in a calcareous cement. 
Bentinck IsLand, near Sweer's Island:-A granular con̈pound, like sand-stone recomposed from the debris of granite. Broron hematite, inclosing quartzose sand.

Pisonia Island, on the east of Mornington's Island, is composed of calcareous breccia and pudding-stone, which consist of a sandy calcareous cement, including water-worn portions of reddish ferruginous matter, with firgments of shells.

North IsLaNd, one of Sir Edward Pellew's group.-Cotirse siliceous sand, concreted by ferruginous matter; which, in some places, is in the state of brown hematite. : Calcareous incrtistations, including fragments of madrepores, and of shells; cemented by splintery carbonate of lime.

Cape-Maria Island; in Limmen's Bight, was found by Mr. Brown to be composed principally of sand-stone. The specimens from this place, however, consist of gray splintery hornstone, with traces of a slaty structure; and of yellowishgray fint, approaching to calcedony; with a coarse variety of cacholong, containing small nests of quartz crystals.

Groote EylandT is composed of sandstone, of which two different varieties occur among the specimens. $\therefore$ A quartzose reddish sand-stone, of moderately fine grain; and a course reddish compound, consisting almost exclusively of worn pebbles of quartz, some of which are more than half an inch in diameter, with a few rounded pebbles of calcedony. The latter rock is nearly identical with that of Simms's Island, near Goulburn's Island on the north coast.

Ghasm Islan d, Winchelsea Isla nd, and Burney's.Island; are of the same materials as Groote. Eylandt: and sand-stone was found also. on the western shore of BuvE-Mud BAY.

On the shore of the mainland, opposite to Groote Eylandt, a little north of latitude $14^{\circ}, \mathrm{Mr}$. Brown observed the $6 \mathrm{com}^{\circ}$ mon sandy calcareous stone, projecting here and there in ragged fragments."

Mongan's Island, in Blue-Mud Bay, north-west of Groote Eylandt, is composed principally of clink-stone, sometimes indistinctly columnar. But among the specimens are also a coarse conglomerate of a dull purplish colour,-including pebbles of granular quartz and a fragment of a slaty rock like potstone: the hue and aspect of the compound being precisely those of the oldest sand-stones. Reddish quartzose sand-stone, of uniform and fine grain. . A concretion of rounded quartz pebbles, cemented by ferrugincus matter, apparently of recent formation.

Round Hill, near Cape Grindall,-a prominence east of north from Blue-Mud Bay, was found by Captain Flinders to consist, at the upper part, of sand-stone. The specimens of S 2

the 
the rocks in its vicinity are, dark-gray granite, somewhat approaching to gneiss, with a few specks of garnet; and a calcareous, probably concretional stone, inclosing the remains of shells, with cavities lined with crystals of calcareous spar.

Mount Caliedon, on the mainland, west of Caledon Bay, consists of gray granite, with dark brown mica in small quantity; and on the sides and top of the hill "large loose blocks of that rock were observed, resting upon other blocks."

A small island, near Cape Arnhem, is: also composed of granite, in which the felspar has a blueish hue.

Smaller of the Mesvilde Iscunds, north-east of Melville Bay*.-A botryoidal mass of ferruginous oxide of manganese, epproaching to hematite; the fissures in some places occupied by carbonate of lime.

MELviLLE BAY.-Granite, composed of gray and somewhat blueish felspar, dark brown mica, and a little quartz; containing minute disseminated specks of molybdena, and indistinct crystals of pale red garnet.

RED Crifrs, south-west of Arnhem Bay; - on the line of the first chain of islands mentioned by Captain Flinders. (See the Map, Pl. I., fig. 3.)-Friable conglomerate, of a full brickred colour, consisting of minute grains of quartz, with a large proportion of ochreous matter.

Mallison's Island. (Map, fig. 4.) - The cliffs of this island are composed of a fissile primitive rock, on which sand-stone reposes in regular beds. The specimen of the former resembles gaeiss, or mica slate, near the contact with granite: the sand-stone is thick-slaty, quartzose, of a reddish hue, with mica disseminated on the surfaces of the joints; and one face of the specimen is incrusted with quartz crystals, thinly coated with botryoidal hematite. . Light gray quartzose sandstone of a fine grain, with a thin coating of brown hematite, was also found in this island:-And a breccia, consisting of angular fragments of sandstone, cemented by thin, vein-like, coatings of dark brown hematite, was found there, in loose blocks at the bottom of perpendicular cliffs.-The specimen of this breccia is attached to a plate of granular quartz, and may possibly have been part of a vein.

The shore of INGLis's IsLand, the largest of the ENGursh Company's Ranoe, (2.2.2. in the Map,) is formed of flat beds, of a staty argillaceous rock, which breaks. into rhomboidal fragments; but the specimen is indistinct. Ferruginous mases, probably consisting of brown hematite, come also from this island.

- The relative position of the islands and bays on this part of the coast is represented in the enlarged Map, Pl. I.

Astell's 
Ast'ElL's ISLAND, north-east of Inglis's Isle. Very finegrained grayish-white quartzose sand-stone;-identical with that of Mallison's Island, and very closely resembling some of the specimens from Prince Regent's and Hunter's Rivers.

Among the remaining islands of this range,-BosanguET's, Cotron's, and Pobassoo's Isles, were found by Mr. Brown to consist, in a great measure, of sand-stone, of the same character with the specimens above-mentioned.

PoBassoo's IsLan D, a small islet south-east of Astell's Isle. - Fine-grained, somewhat reddish sand-stone. Another specimen of sand-stone is friable, of a light flesh-red colour, and apparently composed of the debris of granite. A crystalline rock, consisting of greenish-gray hornblende, with a very small proportion of felspar (Hornblende rock?). - Fragment, apparently from a columnar mass, of a stone intermediate between clink-stone and compact felspar.

Such of the English Company's Islands as were examined by Captain Flinders, are stated by him to consist, in the upper part, of a grit, or sand-stone, of a close texture; the lower part being argillaceons, and stratified, and "s separating into pieces of a reddish colour, resembling flat tiles." The stratadip to the west, at an angle of about $15^{\circ}$.

South-west bay of GoulbuRN's souTH IsLaNd, two hundred and fifty miles west of the Gulf of Carpentaria, (Narrative, i. p. 64.)-Coarse-grained reddish quartzose conglomerate and sand-stone; resembling the older sand-stones of England and Wales, and especially the "mill-stone grit" beneath the coal formation. Fine grayish-white pipe-clay; of which about thirty feet in thickness were visible, apparently above the sandstone last mentioned. Coarse-grained ferruginous sand-stone, containing fragments of quartz, from above the pipe-clay.-The appearance of the cliff from which these specimens were taken, is represented in the view of the bay on the south of Goulburn Island, (vol. i. p. 66); and a distant head in the view consists of the same materials.

Simms's IsLand, on the west of Goulburn's south Island, (Narrative, i. p. 70)-is composed of a reddish conglomerate, nearly identical with some of the specimens above mentioned.

The western side of LETHBRIDGE BAY, on the north of Melville Island, consists of a range of cliffs like those at Goulburn's Island; the upper part being red, the lower white and composed of pipe-clay. The western extremity of $\mathbf{B}_{A-}$ thurst Isi.and, between Cape Helvetius and Cape FourCROY, is also formed of cliffs of a very dark red colour.

LACROSSE ISLAND, at the mouth of CAMBRIDGE Gui.F, about one hundred miles from Port Keats.-Reddish, very quartzose sand- 
sand-stone; from a stratum which dips to the south-east, at an angle of about ten or fifteen degrees. Micaceous and argillaceous fissile sand-stone, of purplish and greenish hues, in patches, or occasionally intermixed;-precisely resembling the rock of Brecon, in SouthWales, and, generally, the "sold red sand-stone" of the vicinity of Bristol and the confines of England and Wales. Fine-grained thin-slaty sand-stone, resembling certain beds of the coal formation, or of the millstone grit, is found in large masses, under an "argillaceous cliff," on the north side of Lacrosse Island.

The specimens from the interior of Cambridge Gulf are from Adonphus IsLAND, and consist of reddish and gray sand-stone, more or less decomposed.

VANSITTART BAY, about one hundred and forty miles northwest of Cambridge Gulf.-Reddish quartzose sand-stone, or quartz-rock. Indistinct specimens of green-stone, with adhering quartz; apparently a primitive rock.

Port Warrender, at the bottom of Admiralty Gulf, about forty miles south-west of Vansittart Bay, (Narrative, vol. i. p. 322, 323.)-Epidote and quartz, in small crystals confusedly interlaced; apparently fiom veins; or nests, but unaccompanied by any portion of the adjacent rock.-The structure in one of these specimens approaches to the amygdaloidal. A compact greenish stone, with disseminated crystalline spots of epidote, and of quartz, and apparently consisting of an intimate mixture of those minerals, is also among the specimens from PortWarrender.

All these specimens are from detached water-worn masses at the foot of Crystal Head, on the south-west of the port. The summit of the head is flat and tabular, and the rocks in the vicinity are described by Captain King as consisting of siliceous sand-stone. Calcedony, apparently from amygdaloid of the trap formation, was also found at Port Warrender.

The epidote of this place is in general of a pale-greenish colour, but is mixed with, and sometimes appears to pass into, spots of a rich purplish-brown. The specimens resemble generally the epidote of Dauphiny and Siberia; but Mr. Levy, who has been so good as to examine them, informs me that the crystals exhibit some modifications not described either. by Haüy, or by Mr. Haidinger in his paper on this mineral, and which are probably peculiar to this locality.

W ATER Islan D, on the west side of Cape Voltaire, at the south-west entrance of Port Warrender, is described.(vol. $i$. p. 395) as consisting of quartzose sand-stone; as is also KATEn Island, in Montagu Sound. And the same rock appears to 
occur throughout the islands on this part of the coast.-(Narrative, i. p. 401.)

Montagu Sound, about five-and-twenty miles south-west of Admiralty GulF, (Narrative, i. p. 400.) -Grayish gramular quartz; like that of the Lickey Hill, in Worcestershire. Fine-grained quartzose sand-stone of a purplish hue, resembling a rock on the banks of the Severn, near Bridgenorth. Gray and reddish sand-stone; apparently composed of the debris of granite, and very nearly resembling that of Simms's Island above mentioned.

Hunter's River, falling into York Sound, on the northeast side.-Somewhat coarse reddish-white sandstone; like that of the coal formation, and some varieties of millstone grit. Fine-grained, reddish-gray quartzose sand-stone, having the appearance of stratification, and resembling the rocks of Cambridge Gulf.

RoE's RIVER, at the eastern termination of York .Sound, (Narrative, i. p. 4.07, 408, 413,) runs between precipitous banks of sand-stone, in nearly horizontal strata, which. rise to the height of three hundred feet.

Careening Bay, between York Sound and Prince Regent's River, (Narrative, vol. i. page 413 ; and vol. ii. page 43 , \&c.) -Crystalline epidote, and whitish quartz, apparently from a vein. Purplish-brown epidote, with small nests or concretions of green epidote and quartz; forming a sort of amygdalord. Conglomerate, containing angular fragments of yellowish'-gray quartz-rock, in a base of compact epidote. A nearly uniform greenish compound of epidote intimately mixed with quartz, also occurs at this place. Flat lamellar calcedony. Very finegrained reddish-gray quartzose sand-stone, with traces of a slaty structure, resembling that of York Sound, and Cambridge Gulf, was found in the north-east end of this bay; and finegrained green-stone, on the summit of the adjacent hills.

Several of these specimens are almost identical with those of Port Warrender; from which place Careening Bay is distant about sixty miles.

Bat IsLAND, (Narr. i. p. 4.32,) western entrance of Careening Bay.-Quartz from thin veins, with particles of an adhering rock, probably chlorite-slate. Quartz, containing disseminated hematitic iron-ore and copper pyrites. Quartz crystals, with calcedony, from nodules in amygdaloid. Quartz with specular iron ore. Green-stone, with calcedony and copper pyrites. A decomposed stone, probably consisting of wacke.-The specimens of trap-rocks from this place are from a cavern.

GreviLI.E 
Greville Island, near the entrance of Prince Regent's River.-Reddish, coarsely granular, siliceous sand-stone; in horizontal strata, intersected by veins of crystallized quartz*.

HALF-W $-W_{A Y}$ BAY, within Prince Regent's River on the west of the entrance, near Greville Island.-Hornblende rock? nearly agreeing with that of Pobassoo's Island, on the northwest of the Gulf of Carpentaria, (See above, p. 141.) Calcedony; apparently from nodules in amygdaloid. Greenish quartz, approaching to heliotrope. Red somewhat slaty jasper, mixed with quartz and calcedony, and containing specular iron ore.

The specimens from this place much resemble some of those from Sotto i Sassi; in the Val di Fassa in the Tyrol, which I have seen in the collection of Mr. Herschel; and which consist of reddish jasper with calcedony, and a greenish finty stone, like heliotrope, - the whole belonging to the trap-formation.

Pornt Cuningham, east of south from Cape Lévêque, and about one hundred and fifty miles south-west of Prince Regent's River.-Very compact and fine-grained reddish granular quartz, with a glistening lustre, and flat conchoidal fractire. This stone, though so compact in the recent fracture, has distinct traces of stratification on the decomposed surface, which is of a dull reddish hue. Bright red ferruginous granular quartz, (Eisen-kiesel?) with a glistening lustre, and a somewhat porous texture. A specimen of "the soil of the hills" at Cygnet Bay, consists of : very fine reddisb-yellow quartzose sand. A large rounded pebble, consisting of ferruginous granular quartz, of a dark purplish-brown colour, and considerable density, was found here; near a fireplace of the natives, by whom it is used for making their hatchets; with a fragment of a calcareous incrustation, like that of the west coast hereafter mentioned.

The next specimens in Captain King's collection,-a space of more than three hundred miles on this coast not having been examined by him, - are from Macus Iscand, in Dampier's Archipelago (See Narrative, vol. i. p. 56):-they consist of fine-grained green-stone, and what appears to be a basaltic rock, of amygdaloidal structure.

Dirk Hartog's Istand, west of Shark's Bay.-A compound of rather fine-grained translucent quartzose sand, $c e-$ mented by carbonate of lime, of various shades of reddish and yellowish gray. This stone has in some places the structure of a breccia; the angles of the imbedded fragments, which are from half an inch to two inches in diameter, being very distinct: - but in other parts, the fracture exhibits the appearance of - Narrative, vol. ii. p. 53. 
roundish nodules, composed of concentric shells, -or bags as it were, of calcareous matter, which vary in colour, and are filled with a mixture of the same substance and quartzose sand : and the spaces between these nodules are likewise occupied by a similar compound *.

The cementing lime-stone in the rock of this island, is very like some of the more compact portions of the stone of Guadaloupe, which contains the human skeletons, the hardness and fracture being nearly the same in both. The chief difference of these rocks seems to arise from the nature of the cemented substances; which, in the Gaudaloupe stone, being themselves calcareous, are incorporated, or melted as it were, into the cement, by insensible gradation + ; while the quartzose sand, in that of Dirk Hartog's Island, is strongly contrasted with

- The following description given by the French naturalists of the rocks at Bernier's Islands, was probably taken from a large suite of specimens; and M. Péron states, (I. p. 204,) that it is serictly applicable to all the adjacent parts of the continent, and of the islands that were examined by the French voyagers :

"Le sable du rivage (de l'île Bernier) est quartzenx, mêlé d'une grande proportion de débris calcaires fortement atténués. La substance de l'île même se compose, dans ses couches inférieures, d'un grès calcaire coquillier, tantôt blanchâtre, tantôt rougeâtre, déposé par couches horizontales, dout l'epaisseur varie de 2 à 3 décimètres, ( 7 à 11 pouces,) et qui toutes étant très uniformes dans leur prolongement, pourroient offirir à la maçonnerie des pierres de construction naturellement taillées.

"Les coquilles incrustées dans ces massifs des roches sont presque toutes univalves; elles apartiennent plus particulièrement au genre Natice de M. de Lamarck, et ont les plus grands rapports avec l'espèce de Natice qui se tronve vivante au pied de ces rochers. Elles sont sans doute petrifiées depuis bien des siècles, car, outre qu'il est très difficile de les retirer intactes du milieu de ces grès, tant leur adhésion avec eux est intime, on les observe encore à plus de 50 mètres ( 150 pieds) au dessus du niveau actuel de la mer.

“Quelque régularité que ces bancs puissent affecter dans leur disposition générale, ils ne sont cependant pas tous homogènes dans leur substance; il est sur-tout une varieté de ces roches plus remarquable par structure. Ce sont des galets calcaires, agrégés dans une terre sablonneuse ocracée, qui leur est tellement adhérente, qu'on ne sauroit détruire cette espèce de gangue sans les briser eux mêmes. Tous ces galets affectent la forme globuleuse, et se composent d'un grand nombre de zones concentriques, qui se développent autour d'un noyau central d'un grès scintillant et brunâtre. Ces diverses couches ont à peinequelques millimetres d'épaisseur, et affectent des nuances agréables, qui varient depuis lè rouge-foncé jusqu'au jaune-clair. Ia disposition générale de cette breche lui donne donc quelques rapports grossiers avec le granit globuleux de l'ile de Corse; et, par ses couches rubanées, concentriques, elle a quelque chose de l'aspect des Agathes-Onyx. ..... Les bancs de grès divers dont je viens de parler, constituent, à bien dire, la masse entière du pays qui nous occupe, \&c."-Vol. i. p. 110. See also Freycinet, p. 187.

+ See Mr. Kœnig's paper. Phil. Trans. vol. civ. (1814) p. 107, \&c.

Vol. 68. No. 340. Aug. 1826. 
the calcareous matter that surrounds it*. But, wherever the imbedded fragments, in the latter consist of lime-stone, their union with the cement is complete.

RotTNEST IsLand, about four hundred and fifty miles south of Dirk Hartog's Island. - Indistinct specimens containing numerous fraginents' of shells, in a calcareous cement; the substance of these shells has at first sight the appearance of calcedony, and is harder than ordinary carbonate of lime.

The characters of the shells in Captain King's specimens from this place are indistinct; ' but the specimens at the Jardin du Roi, which, there is reason to suppose, have come from this part of the coast, contain shells of several species, - belonging among others: to the genera, corbula, chama, cardium, porcellanea, turbo; cerithium.i .M. Prevost, to whom I am indebted for this account, observes, that notwithstanding the recent appearance of the shells, the beds which contain them are stated to occur at a considerable height above the sea: and he remarks that the aspect of the rock is very like that of the shelly deposite of St. Hospice, near Nice.

King George's Sound, on the south coast, east of south from Cape Leeuwin. $\rightarrow$ Beautifully white and fine quartzose sand, from the sea-beach. Yellowish gray granite, from Bald-head. Two varieties of a calcareous rock, of the same nature with that of Dirk Hartog's Island; consisting of particles of translucent quartzose sand, united by a cement of yellowish or creamcoloured carbonate of lime, which has a flat conchoidal and splintery fracture, and is so hard as to yield with-difficulty to the knife. In this compound, there are not any distinct angular fragments as in the stone of Dirk Hartog's Island; but the calcareous matter is very unequally diffused.

A third form in which this recent calcareous matter appears, is that of irregular, somewhat tortuous, stem-like bodies, with a rugged sandy surface, and from half an inch to an inch in diameter; the cross fiacture of which shows that they are composed of sand, cemented by carbonate of lime, either uniformly mixed throughout, of forming a crust around calcareous matter of a spongy texture; in which latter çase they have some resemblance to the trunks or roots of trees.-A mass, which seems to have been of this description, is stated to have come from a height of about two hundred and fifty feet above the sea, at Bald-head, on the South Coast of Australia. These specimens, however, do not really exhibit any traces of organic, structure; and so nearly resemble the irregular stalactitical concretions produced by the passage of calcareous or ferruginous

* Captain King informs me that the soundings in this part of the coast; bring up a very fine quartzose-sand, like that cemented in the breccia. 
solutions through sand*, that they are probably of the same origin; indeed the central cavity of the stalactite still remains open in some of the specimens of this kind from Sweer's Island in the Gulf of Carpentaria. The specimens from Madeira, presented to the Geological Society by Mr. Bowdich, and described in-his notes on that island + , appear upon examination to be of the same character.-But there is no reason to suppose that the trunks of trees, as well as other foreign substances, may not be thus incrusted, since various foreigil bodies, even of artificial production, have been so found. Professor Buckland has mentioned a specimen of concreted limestone from St. Helena, which contains the recent shell of a bird'segg $\ddagger$; and M. Péron states that, in the concretional limestone rock. of the South Coast of New Holland, the trunks of trees occur, with the vegetable structure so distinct as to leave no doubt as to their nature $\$$.

\title{
XIX. Notices respecting New Books.
}

Preparing for Publication.

\begin{abstract}
A TRANSLATION of the Baron Dupin's admirable Course of Mathematics applied to the Arts, and adapted to the State of the Arts in England, by Dr. Birkbeck, President of the London Mechanics' Institution, is in the press and will speedily be published in weekly numbers. Of all the writers of elementary books, the Baron Dupin seems the most fascinating. In the present work, - a transcript of his lectures, - he has succeeded in making the study of mathematics extremely amusing as well as instructive. Such a book has hitherto been a great desideratum in our language, andmust be very acceptable to every student.
\end{abstract}

ANALYSIS OF PERIODICAI WORKS ON NATURAL HISTORY.

G. B. Sowerby's Genera of Recent and Fossil Shells, No. XXIV.

This Number contains the following genera: Oniscia, Pyramidella, Pyrula; Mactra, Eutraria, Tornatella.

Oniscia is a new genus, distinguished from Cassidaria by its granulated inner lip, its 'very short, 'scarcely 'reflected canal, and its very singular general form. The species at present

* Tubular concretions of ferruginous matter, irregularly ramifying throngh sand, like the roots of trees, are described by Captain Lyon as occurring in Africa-Lyon's Travels, Appendix, p. 65.

+ Excursions in Madeira, 1825, p. 139, 140; and Bull. des Sciencex Naturelles, vol. iv. p. 322.

$\neq$ Geol. Trans. vol. v. p. 479. 